\title{
The Nightmarish Odyssey of Women Stuck in the Dystopian Lottery: Sophie Mackintosh's Blue Ticket
}

\author{
İsmail AVCU ${ }^{1}$ (D)
}

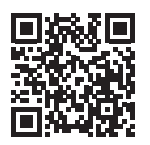

${ }^{1}$ Assist. Prof., Ataturk University, Faculty of Letters, Department of Enlish Language and Literature, Erzurum, Turkey

ORCID: I.A. 0000-0002-8320-920X

\section{Corresponding author:}

İsmail AVCU,

Atatürk Üniversitesi, Edebiyat Fakültesi, İngiliz Dili ve Edebiyatı Bölümü,

Erzurum, Türkiye

E-mail: ismail.avcu@atauni.edu.tr

Submitted: 31.01 .2021

Revision Requested: 16.03.2021

Last Revision Received: 19.03.2021

Accepted: 04.05.2021

Citation: Avcu, I. (2021). The nightmarish Odyssey of women stuck in the dystopian lottery: Sophie Mackintosh's Blue Ticket. Litera, 31(1), 43-74.

https://doi.org/10.26650/LITERA2020-872054

\begin{abstract}
Sophie Mackintosh's Blue Ticket touches upon the issues of gender roles, femininity, motherhood as well as oppression, dystopian restrictions, the abandonment of free will and predetermined life. As a lottery is used in the narrative to determine women's lives, the deconstruction of gender roles as well as a nightmarish system of oppression of women are thoroughly analysed in the novel. Since women's writing and women's issues have become quite relevant and topical today, Blue Ticket offers a deeper analysis and a horrible story about the aforementioned concepts.

This paper aims to show how gender roles and the existence of women are reflected in Mackintosh's feminist dystopian narrative Blue Ticket by making use of Luce Irigaray's, Helene Cixous's and Michel Foucault's theories in which femininity, sex, gender roles, biological representation, and panopticon become prominent. Considering the fact that women's writing and restrictions of gender roles go hand in hand in contemporary British fiction, this study brings out significant results about how Mackintosh evaluates those issues with a unique voice and what her female characters tell the readers about living a pre-determined life. In a world where women are given only two options, which are provided by pure chance in a lottery, of either having a baby or being used for the sexual pleasure of men, the conventional issues of femininity and gender roles are scrutinized with current patriarchal power relations and dystopian regimes.
\end{abstract}

Keywords: Gender roles, femininity, motherhood, womanhood, dystopia 


\section{Introduction}

Welsh-born Sophie Mackintosh is an internationally renowned writer with her novels Water Cure, which was nominated for the 2018 Man Booker prize, and Blue Ticket, published in 2020, both of which touch upon the major elements of dystopian tradition. Approaching contemporary issues in her unique style through themes such as gender roles, freedom, independence, self-realization, and oppression, Mackintosh analyses the issues of women, motherhood, free will, and rebellion in her work titled Blue Ticket. She has become one of the prominent writers in the world of Contemporary British novels with the above-mentioned works and has successfully been a powerful voice in women's literature.

The major points of the novel discussed in this paper have been analysed under the dystopian atmosphere surrounding feminist thought which started with a political orientation that rapidly moved from individual works to a movement aimed at women's liberation in every sense. Besides, feminist critique is a distinct form of political, social and cultural discourse: a critical and theoretical activity devoted to the fight against patriarchy and sexism, rather than just a concern for gender in literature. Feminist scholars have discussed the oppressive construction of femininity and its enforcement of certain social norms on all biological women - by conditioning or programming thus passing them off as normal.

Blue Ticket tells the journey of the main character Calla, starting with Lottery, continuing with Home, Road, Cabin, Beach, and ending with Border. During this journey, Calla, whose fate is determined by some sort of a coincidental system, deforms all relationships and stereotypes in the hostile environment: "It began with the allocating of luck, our bodies pinballs inside a machine. It was the year of overlapping adolescences when the girls started to faint and grow tall" (Mackintosh, 2020, p. 9). Set in a dystopian society, the narrative contains striking elements of mystery and masculine authority. Calla's effort to get rid of the regime that puts preferences related to oppression, restriction, pressure, and marginalization into the foreground or to rebel against this regime, which Althusser clarifies the repressive ones as "the government, the administration, the army, the police, the courts and the prisons $(2008$, p. 17$)$, is felt from the first sentence of the work to the last. 
M. Keith Booker details the definition of dystopian literature in Dystopian Literature: A Theory and Research Guide that:

...dystopian literature generally also constitutes a critique of existing social conditions or political systems, either through the critical examination of the utopian premises upon which those conditions and systems are based or through the imaginative extension of those conditions and systems into different contexts that more clearly reveal their flaws and contradictions. (1994, p. 3)

Although the totalitarian regimes in which women are kept under control are not a new subject, Mackintosh has given a different perspective to the dystopia genre with this pedantic narrative full of question marks. This world, where women are divided into two groups by lottery, tells the story of them with white tickets who are allowed to give birth, and with blue tickets who are forbidden to conceive, should not even think about having a baby, and have the child aborted if there is pregnancy. In the lottery at the beginning of the novel where"...one person's terrorist is another's freedom-fighter, so is one person's utopia another's dystopia" (Claeys, 2010, p. 108), Calla receives a blue ticket, and although she, who by chance succumbs to her determined destiny, seems pleased with her life at first, soon realizes that she cannot restrain the dark feeling and growing desire in her.

Irigaray undermines male dominance in sexual intercourse in that female sexuality is numerous, whereas male sexuality is minimal. She suggests that the sexuality of women is more independent than that of men. Despite having experienced all kinds of sexual intimacies, having sex with men and women, and trying to adapt to her impassioned life based on carpe diem, Calla realizes that she wants to experience motherhood after a while and becomes pregnant. However, when a woman with a blue ticket becomes pregnant, she is excluded from the society they live in and in which are punished severely if they do not have an abortion. Realizing that she will face situations of shame, marginalization, exclusion, and labelling, Calla does not give up her thoughts, and as a result of her talks with Doctor $A$, she rebels against the totalitarian regime she is controlled by and finds herself in an escape to bring her baby into the world despite all the warnings.

Mackintosh details in Blue Ticket a woman who desires something forbidden, a mother who can afford anything for her unborn baby, someone who wants extremely 
fragile and innocent things like a family and a child, a fugitive desiring intimacy, and finally a woman who has to make decisions that go against the basic elements of motherhood and sets out on an uncanny journey. The novel also makes subtle references to today's issues of women, by repeatedly questioning why they have to obey these rules and what an attempt of free will would cost. While women who passionately expect to see their first menstruation, define themselves as unaware of anything, they perceive their lives with a psychological state ready to hand over the colour of the first bleeding to red, the colour of the tickets to blue or white.

The women in Blue Ticket are used only for breeding or sexual pleasure purposes. They have no significance of existence or social entity. The thoughts of Calla, who is dissatisfied with her current situation and does not agree to live by the rules determined by the regime, the past experiences that taught her to survive, her interaction with other women in similar situations, create question marks in the minds of the readers, causing a riveting narrative. This haunting text touching upon concepts of freedom, choice, and will reveals in a terrifying way how in a dystopian society the fate of women is determined by the colours that come out of the lottery, that the decision to have children is left entirely to chance, and that a woman's life is insignificant in every aspect. According to Althusser, "ideological state apparatuses" are prior to the "repressive state apparatuses". This mechanism of normalization is a planned consequence of the philosophy embraced, such that war produces a "representation of the imaginary relationship of individuals to their real conditions of existence" $(2008$, p. 36) in the minds of citizens. These repressive state apparatuses are working mercilessly and relentlessly against Calla and other women.

Considering the structures in which the nightmarish regimes threaten human life and free will, it is possible to talk about the restrictions and psychological torture that each individual is subjected to, regardless of being male or female. As Kumar indicates clearly:

Like utopia, anti-utopia invented the whole social orders, in all their particularity. But while utopian order was perfect, in the moral sense, the anti-utopian order was merely perfected, in the social sense. It was dreadful perfection of some modern system or idea. And while utopian societies were ideal, in the sense of the best possible, anti-utopian society represented merely the victory or tyranny of the idea. In both cases, the reader was 
invited to live the life of a society realized according to some principle. But in the one case the expected response to the experience was delight, in the other, horror. $(1987$, p. 125)

The novel including the full names of women and men only with their initials, reminds us, in an ironical way, not of women's significance, but of a butcher shop where their bodies are shared with the colour of the chosen ticket: "We lined up, waiting to pull our tickets from the machine, the way you would take your number at the butcher's counter" (2020, p. 15). At one point, producing an atmosphere that makes women's skeptical attitude to free will acceptable even creates the perception that an extremely disturbing world awaits everyone: "I felt no great fidelity to the concept of free will" (2020, p. 10). The world that Mackintosh created in Blue Ticket was determined by disturbing events, unacceptable situations, and intriguing reactions, as well as eerie and uncanny decisions. It is so clear to say that what Mackintosh does in her works is closely associated with the concept of women's writing, and as Morris points out:'The Laugh of Medusa' is Cixous's most impassioned appeal to women to follow her example and discover a positive feminine identity through writing. It shares and expresses the excitement and empowerment felt by many women" (1993, p. 120).

\section{Calla's Fateful Lottery}

The first part of the novel, Lottery, tells the reader about the protagonist Calla right before menstruation, reflecting the mood of a person who is unaware of what femininity, sexual intercourse, and relationships with the same or opposite sex mean. As Peter Ruppert states in Reader in a Strange Land: The Activity of Reading Literary Utopias: "One person's utopian dream turns out to be another's nightmare" (1986, p. 98). This world, where no information is given as to why the system is like this, leaving the impression of a post-apocalyptic universe, determines the lives of girls as soon as they menstruate, and causes a different story to start than simple narratives where men put pressure on women. While women's choices, feelings, desires, passions, and impulses are of no importance, the idea that freedom is offered as an illusion is imposed on women. Calla is always eager to accept the ticket that she has to wear around her neck, but she is about to show what will happen when people are stripped off of their ability to choose.

There was chance at the beginning of everything, and women's lives, bodies, choices, psychology were ready to be determined as a result of it: "It began with the allocating 
of luck, our bodies pinballs inside a machine" $(2020$, p. 9). While tickets, which are seen as the right to choose, divide the life of women into having a baby and not having a baby, women who have no other choice but to face the facts such as restrictions, oppression, dependence, and cruelty are forced to live under the rule of violent, ruthless, callous, even rapist men.

Calla states that she is unaware of anything, praying that her menstrual bleeding would begin as soon as possible, but eventually, she seems to wish her fate to be determined by a lottery without knowing what would happen to her, what she does not realize is the fact that she would be a toy in the hands of an oppressive, tyrannical and cruel regime. The sense of satisfaction that she implies in the sentence "One day, finally, there was a red slick in my underwear" (2020, p. 14) is driving Calla towards a process she would later have to face in great pain. When she goes to the lottery centre, which resembles a clinic, the attendant's response "congratulations" (2020, p. 15) shows the intervention to the perception that should be formed in the women's mind. Participation in the lottery is something to be congratulated, an event to be celebrated, and a turning point in life, but it is not seen as restricting or suppressing women's physical and mental spheres; at least this is the case in the beginning.

Calla feels excited before the lottery and she is waiting for her turn. She hears a voice in her mind saying she is prepared for anything, but she would soon realize what it means to determine her life: "I put my hand in it. I was apprehensive but ready for my life to be decided" (2020, p. 15). After the machine deems the blue ticket suitable for Calla, everything is determined and there is no going back. Calla has to live by the rules of the blue ticket all her life, which means she would never have a baby. The rules are clear and her life could be in danger if she breaks the rules; rebellion is a big and inexcusable crime. Calla realizes that her life is determined with the blue ticket, only when the officer tells her "you have been spared, she said with a terrible benevolence" (2020, p. 15). In the group with Calla, the white ticket goes to only one person, and that person is treated differently from the blue ticket: "The girl with the white ticket was escorted into a separate room by the doctor and another emissary" (2020, p. 15). Nobody knows why, and nobody cares.

After the blue ticket is chosen, a series of testing and reporting takes place, and Calla would now live in this dystopian world by constant pursuit. She has to be checked by a doctor before she could start her new life. Although there is no exact information 
about what this procedure is, the implication is that it is related to the tracking system: "I lay on a reclining bed with a crisp paper cover, and another doctor, this one a woman and comforting, almost, in the familiar white coat, told me to fold up my knees. She pushed something inside me that hurt, a sharp and spidering pain" (2020, p. 16). The doctors who examine women after the lottery are mostly men, but Calla's last check-up before she starts her new life is done by a female doctor. This is a terrible fact showing that female doctors are used against women in the dystopic regime. Women whose lives are determined by lottery, who are deprived of free will and have to live one of two lives are forced into this process by female doctors who also become a part of the nightmarish system.

Right after her fate is determined by the blue ticket, Calla could now begin her new life. Although she seems content after the lottery, she is not sure what it means to have children throughout her life. Having a child seems like torment to Calla at first and she would realize later that the opportunities for her female identity, female lifestyle, self, and free will have been taken away, but for now, she thinks she enjoyed the result of the lottery: "I would never have children. And I was glad. I had been a child myself, not so long ago. I did not want to put any other puny creature through that" $(2020$, p. 17). The problem is not only the determination of the fate of women and the decision of their lives by chance. In addition to that, there are signs of discrimination between the blue ticket and white ticket holders. There is a distinction that starts with food and drinks given to those who attend the lottery, and the victims of the regime that restrict women's lives are also discriminated against among themselves: "The bottle given to the white-ticket girl was larger than ours, I noticed, and she received two sandwiches. It was happening immediately, the diverging of our paths, no time to spare" (2020, p. 17).

The girls whose lives were determined by the lottery are now ready for something new, but they do not know how to start or where to go. Since they are not used to making decisions about their lives, they also need guidance in their next steps. "They didn't know where to go" $(2020$, p. 17) and they seemed lost from the very beginning; a life devoid of concepts such as the sense of belonging, social identity, self-realization, and self-awareness awaits them. Their lives would now go on with acceptance, they have no choice but to accept whatever comes and is determined for them: "That's how your life becomes a set thing, written and unchangeable. It was an object that did not really belong to me, and to wish for any other was a fallacy at best, treasonous at worst" 
(2020, p. 19). As Booker exemplifies, "[t]he principle technique of dystopian fiction is defamiliarization: by focusing their critiques of society on spatially or temporally distant settings, dystopian fictions provide fresh perspectives on problematic social and political practices that might otherwise be taken for granted or considered natural and inevitable" (1994, p. 19). Everything is determined by the blue ticket, and the things that Calla is not allowed to do are now clear. There is no questioning of female identity, and being able to decide freely. The women have no other choice but to accept their destiny determined within this system, and the warning about this soon appears before Calla: "Choice is an illusion, said a woman redoing her lipstick next to me in the bathroom mirror of a bar one evening. Don't you ever think about how everything is just completely futile?" (2020, p. 20).

With the pervasive dominance of the lottery as the determinant machine and the tickets carried by every female character in the novel, some sort of auto-control is produced in the system like the apparatus that Foucault explains in Discipline and Punish:"This architectural apparatus should be a machine for creating and sustaining a power relation independent of the person who exercises it, in short, that the inmates should be caught up in a power situation of which they are themselves are the bearers" (1995, p. 201). Distinct examples of the dystopian tradition, in which elements about the abolition of free will, restriction on thought, oppression, cruelty, and total control are widely used, catch Calla's attention. She wants to question before she immediately acknowledges the woman's warning to her, and she doubts them. Such women could be a trap for blue-ticket holders who hide their true feelings, and women who become enemies of each other to expose their fellows face more than just gender discrimination: "...one day they seemed like secret agents out to seed the word of independence, of pleasure-seeking and fulfilment" (2020, p. 21). Calla enjoys discovering new experiences as time progresses, taking advantage of the order in which she lives, but at times realizes that she is not psychologically healthy and strong.

A barbed wire effect in her psychology started to haunt her dreams and she feels bizarre about her predetermined life: "Some nights I dreamed I was caught in a dark room with no windows or doors, a room from which there was no way out, and there was a pain in the centre of my chest, below tissue and bone, a pain that was part of me, though I resented and feared it" (2020, p. 21). She could feel the real pain inside even though she has a dream and she starts to recognize that women with white tickets are the privileged ones; blue tickets are inferiors: "The white-ticket girl in the back of a 
car driven by an emissary from the lottery building. She had rolled the window down, a sliver of her face pressed to the gap. She looked wild, but I do not think she was being stolen away. She was being protected" (2020, pp. 21-22). After that moment, Calla starts to become aware of something different about herself and her womanhood. She is restricted and oppressed in this system and something dangerous would be dominant in her decision-making process and that is uttered by her out loud: "It wasn't fair. Sometimes I came out from the dreamed dark room with those words on my lips, as if I had been saying them over and over. It wasn't fair" (2020, p. 22).

She feels the difference and starts to be curious whether the white-ticket women feel the same thing that their lives should be destroyed or changed somehow. Soon enough, Calla realizes the restrictions put on her life by the lottery and has a feeling of rebellion with a growing passion inside:

In its place came desires so alien that I could only assume they had been inside me for a long time...I was reaching for my locket and looking at the unspoiled blue and thinking: white ticket. I was thinking that a mistake might have been made somewhere and the life I had stepped into was the wrong one. Road not taken, or rather a road closed off to me. (2020, p. 22)

There she starts to think of Robert Frost's The Road Not Taken where she gets curious about the other path she is not allowed to choose. She wants to choose for herself now and this choice is the forbidden road; her life has already been decided by the lottery but Calla feels a deep desire, a strong rebellion inside and dares to change her whole life: "It was between me and my desire: stringy as the rind of a bean, me and it alone at night, with the moon shining down, and the only path visible was one absolutely forbidden to me. And yet I wanted it, wanted it, wanted it" (2020, p. 23). Calla, who wants to choose forbidden ways, emphasizes making decisions of her own will while rebelling against the system that restricts women's identity.

\section{New and Dark Feeling inside the House of Cards}

While Calla is busy getting to know her own body after going from girlhood to womanhood, "for weeks there ha[s] been a new and dark feeling inside" (2020, p. 25). The effects of this new feeling on Calla's body, psychology, decisions, and choices would soon become evident as Cixous points out the bond between man and woman as day/ 
night with light/dark hegemony. Like the day after night, a man is superior to a woman. Women are dark for men, and "dark is dangerous." However, Cixous defies this by stating: "We the precocious, we the repressed of culture, our lovely mouths gagged with pollen, our wind knocked out of us, we the labyrinths, the ladders, the trampled spaces, the bevies - we are black and we are beautiful" $(2008$, p. 878$)$. Her body, which she is trying to recognize with her hands, seems to belong to deep and incomprehensible darkness. When Calla remembers her thoughts about the past, she realizes she did not miss the times she was a little girl. What she did was to live life with her female identity, the female body, and the destiny determined for her. Although their lives are determined by lottery, Calla is interested in what she wants as if she were making choices with her free will: "Girlhood was gone. Girlhood was over and dead for us all. We didn't miss it. In its place, anything could happen" (2020, p. 29).

Irigaray starts "This Sex Which Is Not One" with the following statement: "Female sexuality has always been conceptualized on the basis of masculine parameters" (1985, p. 23). In this constantly controlled system of restrictions, the blue-ticket Calla is aware of the possibility that her life could change at any time, and this life in a nightmarish atmosphere, could change in some way, but it is not clear what Calla would encounter. Following her desires or emotions is not something appreciated in a system where life is predetermined. During this period, when Calla experiences sexuality and tries to understand her femininity, she feels the disturbing presence of the change that could take place in her life: "If you were a blue-ticket your life could change at any time, you could make it change at any time, and we were alternately complacent and anxious about the possibilities contained within that freedom" $(2020$, p. 29). This feeling is a sign of darkness emerging within her every day.

Calla, who is intoxicated at every opportunity due to the uncertainty and dark feeling she is surrounded by, meets a man while spending time with her friends in a similar evening at a bar and feels complicated emotions in her. As stated throughout the novel, $\mathrm{R}$ is the person who confronts Calla, one of the male characters whose names are not given exactly. When left alone, Calla, not knowing what to do due to uncertain emotions, suddenly decides to show her ticket on her necklace and realizes that $R$ wants someone with a blue ticket. The intimacy and physical contact between them results in an expression of Calla's confusion and feelings about the life presented to her. Calla, who likes the moment when $\mathrm{R}$ kisses her, realizes that after a few seconds, the dark feeling in her takes over: 
He kissed me hard on the mouth and I put my fingers through his belt loops and pulled him against me for a second, several seconds, before pushing him away, both my palms against his chest, then running to the train station over the street covered with rain, exultant, my body full of the dark feeling, not turning back, though I knew he would be looking. (2020, pp. 30-31)

The kissing between Calla and $\mathrm{R}$ is like a trigger of that dark feeling. As a result of this intimacy, which she first likes, Calla faces making the most important decision of her life. The more she tried to recognize her feeling through the female body, the more she feels lost in the dark: "The dark feeling by then was a shimmering, liquid thing, like a pool of blood or a black opal. It was a kind of raging joy, is how I can best explain it" (2020, p. 31).

According to Barbara Smith, "[f]eminism is the political theory and practice to free all women: women of colour, working-class women, poor women, physically challenged women, lesbians, old women, as well as white economically privileged heterosexual women" (qtd. in Kolmar et al., 2005, p. 8). This growing dark feeling is in a position to show what kind of a woman Calla is and the physical intimacy with $\mathrm{R}$ helps her assess the situation about herself. The life determined by the blue ticket and what it brings does not match well with what Calla feels. There is now a radical change for her. Rebelling against the rules of the system, opposing restrictions and having a predetermined destiny at all costs, not submitting to the regime that determines the female body and the needs and desires of this body with the factor of chance and lottery emerges as a result of Calla's awareness of her femininity:"And I knew very well what sort of woman I was, and I did not want to be that woman anymore" (2020, p. 31).

As for sex that should be mutual, the role of women in society is more prevalent as a tool for reproduction rather than an active part of it. When Calla sees the condom before having sexual intercourse with $\mathrm{R}$, she utters a sentence implying what she wants, saying "You don't have to," (2020, p. 35); to become a mother. After having sex three times that night, when R leaves the house, Calla realizes that she enjoys sex, but having a baby sounds much more exciting. It is not just being a mother that determines a woman's identity, of course, but in this system where it is not decided how to represent her femininity, Calla is aware that she is embarking on a great task by opposing her determined destiny and is willing to pay the price of denying what the system imposes. 
The thought of having a baby haunts her and she keeps wondering what kind of presence that would be in her body: "Sometimes before I slept I put my hands on my stomach and felt a deep pulse that I was sure must be its visible manifestation" $(2020$, p. 35).

Getting pregnant is illegal for women with blue tickets in this lottery-ruled environment, and Calla does not know what happened to those who had become pregnant. She is trying to understand what motherhood feels like. "... maternity fills the gaps in a repressed female sexuality" as Irigaray states $(1985$, p. 27$)$ and Calla could not understand whether it was an innate thought or an afterthought. Another thing she could not perceive was whether there was any power to take that feeling off of Calla: "Was motherhood something that could be halted on command, something they could compel out of you once discovered? Was it something you had to see through regardless?" (2020, p. 36). What she thinks of is a dark feeling, and it is now uncontrollable. Whatever Calla does, there is no legal way to do what she wants, because "there was no way to change your ticket" (2020, p. 36).

Calla feels the same overwhelming feeling whenever a child is seen or mentioned. She is aware of how important motherhood becomes in her life, although the person in front of her talks about how difficult baby care is, and dealing with children is like torture. Before this dark feeling arises, she thinks "my time belonged to me, my life was only mine" (2020, p. 38), but as she hears the voices of children and sees them, those thoughts she had previously felt were "all evaporated" (2020, p. 38). All this aside, Calla, having sex with $R$ regularly and leading the relationship in a certain routine, is determined not to reveal anything. It is more of a robotic or mechanical set-up between them, doing what they need to do; $R$ is sexually satisfied, while Calla uses $R$ to make real the idea of having a baby and get pregnant. Despite this, Calla, having expected some meaningful reactions from $\mathrm{R}$, could not solve the complicated situation she was still in: "He came to act less respectfully with me fairly soon. No more talk of prophylactics, for example. I started to mind a little, even though it was part of my plan" (2020, p. 41). Perhaps she feels that $\mathrm{R}$ should show more attention as the father of the future baby. As Irigaray asserts concerning that:

For woman is traditionally a use-value for man, an exchange value among men; in other words, a commodity. As such, remains the guardian of material substance, whose price will be established, in terms of the standard of their work and of their need/desire, by "subjects": workers, merchants, 
consumers. Women are marked phallically by their fathers, husbands, procurers. And this branding determines their value in sexual commerce. Woman is never anything but the locus of a more or less competitive exchange between two men, including the competition for the possession of mother earth. (1985, pp. 31-2)

While $\mathrm{R}$ is talking about himself, he explains at least what kind of role men play in Calla's system. They "didn't have the lottery" (2020, p. 42) but it does not mean that "it was easy for" (2020, p. 42) them. For Cixous, these oppositions often have their views on human sexuality, and "... the question of sexual difference is coupled with the same opposition: activity/passivity" (1996, p. 138). While the reactions of the two of them when they have sex indicate that it does not make sense, Calla tries to get to know her own body while beginning to understand what her body means for $\mathrm{R}$, and between her legs is the most important place in this regard, both for Calla and for R: "stroking the little smooth spot of my clavicle where his hand had pressed too hard. That spot was his favourite part of me and I couldn't see why, what had made him fixate on this unassuming piece of bone among all the things that made me up. I had an idea it might be about fragility" (2020, p. 43). Another prominent point about men is that they, too, suffer from a patriarchal culture, according to Cixous. The position of men is decided by society, like that of women:

By virtue of affirming the primacy of the phallus and of bringing it into play, phallocratic ideology has claimed more than one victim. As a woman, I've been clouded over by the great shadow of the scepter and been told: idolize it, that which you cannot brandish. But at the same time, man has been handed that grotesque and scarcely enviable destiny (just imagine) of being reduced to a single idol with clay balls. And consumed, as Freud and his followers note, by a fear of being a woman! (2008, p. 884)

Although Mackintosh's society seems a very ruthless structure for women, it also creates a restricted and pre-determined role for men, especially when they are mostly functioning as pleasure-giving and dominance-forming phallocentric bodies.

Calla, who could not fully comprehend what femininity, motherhood, and sexuality are due to the rules and restrictions imposed on her, does not know much about pregnancy, and how she would feel if she were pregnant:"I was hoping and not-hoping. 
I was indifferent. No; that's a lie. I wasn't indifferent at all. But to admit how much I wanted it was a shame even I couldn't articulate" (2020, p. 44). Calla's life is somehow an experiment. She has to do what is expected, whatever is determined she has to comply. But the dark feeling, increasingly taking control of her, is ready to counter all this. What she opposes is the system that makes it possible to determine women's identity by pure chance. On her first visit to Doctor A after Calla thought she was pregnant, she understood more or less what she was going to face. Either the doctor would have the baby aborted, or Calla would be sent somewhere she did not want, and Doctor A said it would be a bad trip. According to the doctor, Calla was unlikely to escape all this: "Listen to me, Calla. How many chances do you get to make a fatal mistake and have it reversed-forgiven? They'll come for you. There's no escaping it" (2020, p. 51). This means the beginning of an impossible escape and a gruelling journey for her. At the end of the impossible getaway, there is motherhood achieved by free will and the liberation of female identities.

Calla is constantly thinking about motherhood, fatherhood, and having a baby and she is calculating what her decision would cost. It is unclear whether there would be anyone to support this process: "What made a father? What made a mother? What was the thing I was lacking? R was holding out for somebody who would not crawl around on the floor" (2020, p. 56). Her belly is growing big, and it is time to have a serious conversation with $\mathrm{R}$ about it. She wants to talk about the dark feeling inside, the uncontrollable emotion, but she does not know what kind of reaction she would face. Irigaray states that: "Woman's desire would not be expected to speak the same language as man's; woman's desire has doubtless been submerged by the logic that has dominated the West since the time of Greek" (1985, p. 25). When Calla hears of R's thoughts about having a baby, it becomes obvious that she is going to be alone. $\mathrm{R}$ does not care about motherhood or femininity; he is more in the role of someone who uses women to meet his own needs: "I don't know why anyone has a child at all, blue or white ticket, he said" (2020, p. 59). The fact that Calla would have a baby is extremely disgusting for $\mathrm{R}$, and after learning of her pregnancy, it is explicitly revealed what this fact means for her with the sentence "I can't even look at you" (2020, p. 60). Calla knows for sure that she is alone in this difficult escape and "... break[s] out the snare of silence" and becomes "I-woman, escapee" (2008, pp. 881-879).

As a woman with a blue ticket, Calla, having rebelled against the rules, grasps that $\mathrm{R}$ does not feel anything when she is about to make love with him for the last time, 
and realizes this decision placed her in an inferior position in society. Irigaray takes this dilemma further by shifting from the inferior role of women in sexuality to gender inequality at both epistemological and ontological levels:

... the issue is not one of elaborating a new theory of which woman would be the subject or the object, but of jamming the theoretical machinery itself, of suspending its pretension to the production of a truth of a meaning that are excessively univocal. Which presupposes that women do not aspire simply to be men's equals in knowledge. That do not claim to be rivalling man in constructing a logic of the feminine that would steal take onto-theo-logic as its model, but that they are rather attempting to wrest this question away from the economy of logos. $(2004$, p. 571)

Calla becomes someone who tries to disrupt the social order and is therefore excluded by women. R's humiliating behaviour towards her is only the beginning of this exclusion process: "I can't see you in that way, now, he said, pushing me away. It's just no good. You've ruined it all. He was angry at himself and at me" (2020, p. 71). While pregnancy and motherhood mean self-determination and free will for Calla, for $\mathrm{R}$, however, it is just as disgusting, vile, and humiliating. This situation is not simply a problem between men and women, it is a matter of defining or excluding a space related to the order of this world. Calla, who is first sent out of this area by $R$, now makes him sick: "He looked at me. You know, there was a time when I thought I could feel something for you. But not now. Now you disgust me" (2020, p. 72), which is a clear indication of use and abuse system.

In her next meeting with Doctor A, Calla, curious about the doctor's opinion about motherhood and being a wife, asks the doctor to answer without considering the thought that her fate is determined: "Do you think l'd make a good wife and mother? I asked Doctor A. Forget about the journey for a second. Forget that I'm a blue-ticket" (2020, p. 74). She is furious when the doctor answers 'no' without hesitation. Doctor A gives her an unwanted answer too, which turned into a growing fire in loneliness and solitude. Although Calla does not know enough about femininity, motherhood, and the female body, she has all the reasons to go on an extremely dangerous journey. She is about to leave the rules brought by the order behind and start a new life. She feels alienated from everyone she met before the journey and every experience except pregnancy. This is not the place and the world she belongs to. Calla, who openly 
experiences that she is excluded by her fellows after her pregnancy is found out, with the reaction she faces just before her departure and after seeing the booing of women, realizes that she belongs nowhere but to be on the road: "The hissing grew as I checked the boot. I couldn't help myself and looked back to find a wall of women, hard-faced, inching past the territory of their front doors" (2020, p. 84).

\section{Calla's One-way Ticket in the Odyssey of Motherhood}

In the third chapter, Calla's dangerous journey, the confusions, and threats she faced are unearthed. Although a growing baby and a dark feeling getting stronger with each passing day makes Calla more courageous and confident, she prefers to lie to those around her in order not to endanger her baby's life. She even hides her blue ticket and puts a fake white ticket inside the necklace. Telling lies about the father of the baby, she realizes that the identity confusion she experiences while pretending to be with a white ticket would not bring good results for her. Because she rebels against the system and disregarded the rules, she sometimes likens herself to an animal escaping from a predator, sometimes a doll, and this escape implies a process of survival:"I was a warmblooded female animal. I was a doll with another doll inside of me. I was the chicken I opened up one day only to discover that the stomach had been left in by mistake, a pearlescent bag still full of grain from its final meal" (2020, p. 87). On this irreversible path, Calla confronts the system that determines women's lives and limits their identity, and the journey is fraught with countless possibilities for her revolt to fail.

While chatting with a man she meets at a bar during the journey, Calla, having noticed that the pleasure she got from sex and the things she was affected by men changed, confesses when asked who she is, and replied "I'm nothing" (2020, p. 98). This answer is an indication that Calla's identity makes no sense in the system. Remembering that it does not matter to her father, Calla has never felt important when she becomes an adult after her menstruation. The relationship with $\mathrm{R}$, the treatment she faces after she becomes pregnant, and the characterization of her presence as disgusting and unbearable are all solid proofs. The purpose of the system is to make women feel unimportant. Whether they have a baby or not, women who have to live according to the ticket with predetermined conditions are responsible for playing the role assigned to them within this discriminatory regime. Calla, who opposes this role, has to bear the consequences of her uprising. 
Seeing an animal in a dream and being on the run constantly, starts to define Calla's sense of belonging with this escape: "In the night I dreamed of being an animal of the dark, and it was a comfort, for it was confirmation that I belonged" (2020, p. 108). It is this escape that she now feels she belongs to and meets Marisol while wondering if there are others in the same situation. Marisol realizes at a glance that Calla has a blue ticket and is acting against the laws of the system because she knows both femininity and motherhood. Besides, Calla still plays the role of someone who is trying to get to know her body and make sense of the feelings of a woman who is about to be a mother. She aims to end the dangerous journey as soon as possible and reach the border, and she knows she cannot do it alone.

Irigaray explains the struggle of women to settle in this systematics:"There is, in an initial phase, perhaps only one'path', the one historically assigned to the feminine: that of mimicry. One must assume the feminine role deliberately. Which already means to convert a form of subordination into an affirmation, and thus to begin to thwart it" (2004, p. 570). Whenever she encounters danger, Calla lies that her husband is protecting her and tries to survive with her imaginary husband figure, but this void in her life also reveals the need for a masculine existence suitable for gender roles for her. She occasionally dreams of $\mathrm{R}$ being with her, and every time she lies, she imagines that she is with R. The void of the husband's role is also related to Calla's fear. Feeling vulnerable and alone again points to a man's protective and controlling presence. The absence of the baby's father, or the absence of any man, makes Calla more vulnerable or defenceless: "I didn't want to know that everything was trying to kill me. Strange, to be so truly vulnerable" (2020, p. 122). Although this situation seems to contradict the rebellion represented by Calla in this system where the female identity is restructured, she has not yet been able to get rid of the role imposed on her by the society and the maledominated entity that has always been defined as dominant in women's life. Therefore, it may be considered normal for Calla to feel this way for a while.

The contradiction Calla feels within is not only related to gender roles but also to the definition of the unborn baby. Her rebellion problematizes the roots to which the baby belongs or the reason for its birth too. The position of women is subordinate in traditional and patriarchal families and it serves to reflect masculine dominance. Through their children, they only exist. The position of women is also described by Irigaray through this statement: "The mother stands for phallic power; the child is always a little boy; the husband is a father-man. And the woman? She doesn't exist" (2004, p. 575). 
The growing thing in Calla's belly makes her rebellion confusing: "The baby, my own bad baby come from badness, was sucking the marrow from my bones" (2020, p. 125). One of the reasons for this is that Calla, having little idea about phenomena such as motherhood, having a baby, and being a woman, only acts with a dark feeling inside. The inability to fully recognize her body reveals the astonishment of someone who is confronted by a dead-end at some point and Calla intensifies her inquiries with the insecurity of being left alone and finally becomes uncertain where to go:"I have blindly obeyed you, I told my body. I have followed you wherever you want to take me. Now what?" (2020, p. 127).

Calla, struggling in the decision-making process with the fear and loneliness of not knowing where to go, even thinks about asking $\mathrm{R}$ for help one last time, as she contemplates that she cannot continue in this way. Asking $\mathrm{R}$ for help, who said he could not look at her face and who disgusted her after the decision of having a baby, shows how desperate Calla felt:"I want you to say that you love me, I said. I want you to come and rescue me and be a family with me and the baby past the border. I think it might be possible, but only if you come now" (2020, p. 129). Although Calla's feelings for $R$ remind her of a woman who accepts the role set for her in the male-dominated society, her call for help stems from not fully recognizing her own body and sexual preferences. Having the role of a woman who has no choice but to be with men after the tickets are determined creates the perception that there is no alternative. This void Calla feels inside is not something that a man can fill, but a partner can who is able to understand what Calla is going through. $R$ also does not have the qualifications to fill this void and responds negatively to Calla's last call for help.

When Calla sees that her last effort goes in vain, she wants to put all the risks aside and comfort herself with alcohol and pointless sex as she did in her old days. Although what she does is dangerous for her baby's life, her loneliness and desperation cause Calla to be unable to use her decision-making mechanism healthily. All she wants is to have meaningless sex and escape the realities she faced, just to forget her situation:"I wanted to fuck and to be fucked until I was outside of my own head, I wanted a barrel of alcohol, I wanted mind-altering drugs, I wanted to slit his throat - but it was all gone into another world" (2020, p. 138). As women's "desire is often interpreted, and feared as a sort of insatiable hunger, a voracity that will swallow you whole" $(1985,29)$, these facts are similar to those faced by all women in traditional societies; being a mother, housewife and having a docile role. Supporting the aforementioned idea, Fiske and 
Stevens clarify in their work "What's So Special About Sex? Gender Stereotyping and Discrimination":

The descriptive component of the female stereotype includes the following attributes: emotional, weak, dependent, passive, uncompetitive, and unconfident. The prescriptive component of a stereotype is composed of behaviours deemed suitable for the target group. For example, the female stereotype includes the following prescriptions: A woman should have good interpersonal skills, she should be passive and docile, and she should cooperate with others. (1993, p. 179)

In this lifestyle imposed by the system, Calla's domestic role is the role of a woman who cannot have children but will obediently say yes to whatever her husband says to make him sexually satisfied. Although Calla chooses to be a mother, this decision makes her a rebel against the system, but this revolt is no longer as strong as it was in the early days:

On the bed I cried, silently, because he couldn't see me. Because nothing was going to make me feel better, nothing was going to be enough. I cried for the absence of women I had seen on the road, for having to do this alone. I cried because R didn't want to have the baby with me and because Doctor A was my enemy and he wasn't going to save or fix me. (2020, p. 138)

It is disturbing for men to act against the rules of someone with a blue ticket, women are also enemies of Calla, and one of these enemies catches Calla off guard in a bar toilet. Realizing that Calla is pregnant with a blue ticket, the woman attacks her and tries to strangle her: "I know what you are, said a woman's voice. Her hand moved to my throat and squeezed, fingers in the soft spaces under my jawbone" (2020, p. 151). The system exposes the rebels to all kinds of dangers. Women with blue tickets and with white tickets could be enemies to each other. Regardless of their situation, women having continued their lives like robots who did nothing but fulfil the role assigned to them could see those opposing the system as enemies. Calla knows she is alone on this road and has no choice but to stay alive to keep going. If she has to resort to violence against her kind, she is ready to react in this way: "I pulled us both up and scrabbled for the knife in my pocket, pressing it roughly to her throat. It was the blonde woman 
from the bar" (2020, p. 152). Calla has a better grasp of her situation after this moment. She thinks of herself, of white tickets, blue tickets, and Marisol: "I wondered what the white-ticket women felt. Were they fulfilled and serene in their purpose, or did they, too, see the world as a sharp, cutting thing; did they, too, have a dark feeling under their skin, pulsing with violence?" (2020, p. 155). She knows right away that she needs help to see what kind of identity she has, and she no longer needs to hide behind the fake white ticket. It is Marisol who reminded her of this: "Rip it up, she said, giving me the white one. Rip it as small as you can manage. You're not one of them" (2020, p. 156). Calla is no longer a person with a blue ticket or a white ticket. She is an expectant mother now ready to make her way.

\section{Psychologically Imprisoned Women in the Cabin of In-betweenness}

Marisol and Calla, after dodging the danger they face, continue their journey for a while and then find a cabin where they could feel safe. This place, located in the forest and belonging to an environment isolated from life, is also described in a quality that evokes the cooperation of nature with women. Now, two pregnant women with blue tickets, Calla and Marisol, feel the strength of breaking the rules, rebelling, and not accepting the terms imposed by the system. This cabin is important to get to know their bodies better and to share things. Marisol seems to be aware of everything in Calla's position and is a guide to her about motherhood, pregnancy, and female identity.

In the early days, they are hiking in the forest and assessing their situation by thinking aloud and trying to identify their position in this society: "My name is Calla, and I am going to have a baby. Soon. My name is Calla and this baby is mine" $(2020, \mathrm{p} .162)$. These words uttered by Calla are important in terms of reinforcing what awaits her in life now. The same thing is true for Marisol, who states that she wants to have a baby to understand her reality in this world: "My name is Marisol and I want to bring something into the world, she said. Something real" (2020, p. 163). The sharing is important to both of them, but Calla has not yet realized the main reason for desiring to be a mother: "My name is Calla and I want to be a mother because. Because" (2020, p. 163). While trying to express this out loud, her sentence is incomplete. It might be a sign that there is an incompleteness in her identity. Perhaps her femininity, motherhood, destiny, and life are not complete. Therefore, she could not say anything after the word "because". That is the right thing to do for her, according to the inner voice she has. In fact, beyond 
being a mother, what Calla looks for is choosing what she wants. She could not accept that her fate is determined by a lottery. She has a rebellious nature from the beginning, and she is waiting for it to appear. Being able to choose means freedom, determining what kind of life she would live, not accepting the lottery, and choosing to be a mother despite being forbidden are all in line with the dark feeling Calla has: "My name is Calla and I wanted to choose" (2020, p. 163). Having the right to choose means freedom or self-fulfilment of female identity for Calla and women like her. The right to choose, combined with the dark feeling, leaves no other option but to revolt against the system.

Having clear thoughts about men after her previous experiences and disappointments, Calla feels that she has different feelings for Marisol. Marisol is Calla's companion and supporter but she is also important in clarifying some questions about Calla's sexual orientation. As Irigaray states:

...woman's autoeroticism is very different from man's. In order to touch himself, man needs an instrument: his hand, a woman's body, language ... And this self-caressing requires at least a minimum of activity. As for woman, she touches herself in and of herself without any need for mediation, and before there is any way to distinguish activity from passivity. Woman "touches herself' all the time, and moreover no one can forbid her to do so, for her genitals are formed of two lips in continuous contact. Thus, within herself, she is already two but not divisible into one(s)-that caress each other. $(1985$, p. 24)

Although her relationship with $\mathrm{R}$ seems to be fine until Calla becomes pregnant, R's acting by the role that the system expects from men and his prejudiced approach towards women influences Calla's perspective. The reason for having these feelings for Marisol is not only her disappointment with the men but the likelihood that her intimacy would be much more meaningful because of the things she has in common. This is felt when Marisol first kisses her on the lips: "Let it into you, I thought there, in the moments before she pulled me up and kissed me on the mouth for the first time. Let it into you" (2020, p. 164). Thus, women restricted by the system and forced to live a life determined by the regime could interpret sexuality as mutual sharing after homosexual experiences.

Marisol helps Calla perceive the existence of men as well. It is enough to humiliate women that they are extremely inefficient and indifferent to understand their emotions 
and that they think about nothing but bodily satisfaction. Women with a predetermined fate are pieces of meat constantly used and abused in this system, according to the men, and the colour of the ticket determines their life and sexuality. Marisol says it should not be like that. Besides the rules they do not accept by being pregnant, she also states that men "can all go fuck themselves" $(2020$, p. 172) which is a clear sign of exclusion of male dominance in their lives.

On the first evening at the cabin, Valerie, who was once subjected to violence, admits that she unintentionally got pregnant, but then took care of it. The four women in the cabin have blue tickets and are all pregnant knowing that they are forbidden to have a baby. The fifth woman with a white ticket, Therese, states that although she has the right to conceive, she wants to make her own choices. This means that all five women have a common feature. Valerie, who deliberately had a miscarriage, was treated in the same way by the man she was with like Calla:"My husband found out. He didn't believe that it was an accident. He was disgusted with me. But it wasn't his body" (2020, p. 183). The common problem that faces all the women in the cabin is that another system that makes decisions about their bodies. No matter what colour ticket she has, the woman has to determine her own life. While blue-ticket holders define themselves as lacking in this system, Valerie seems like the main defect: "I don't see it like that, she said. If anything, I'm the one found lacking. All my life I've been told I can only be complete if I grow something inside of me and bring it into the world. Whereas you are whole and perfect as you are" (2020, p. 188). In fact, all women who accept the life imposed on them are somehow incomplete.

When Marisol talks about her job as a doctor in the past, she expresses how much she wants the possibility of the system giving her a chance. However, despite all this and meeting every expectation of the system, the fact that they did not give Marisol a choice once again reveals how brutal the situation women are in is: "I tried my best to demonstrate my suitability, I tried to be maternal at every opportunity. But there is no choosing" (2020, p. 196). Knowing this situation, trying to choose for themselves shows the fact that a mother can do anything, even if it means getting into a dead-end. Marisol makes this clear to Calla, and it seems as if both Calla and Marisol would face such a situation in the future which functions as a foreshadowing: "You'll do anything for your child, and I mean anything. Worse things than you've ever imagined" (2020, p. 198). Motherhood, which reduces the role of women to limited space, put Calla and others like her in a position to take all kinds of danger after having a child. This is also 
an example that problematizes the issue of being able to make decisions with a free female consciousness.

Therese's death is the most serious warning for the women in the cabin. When they encounter her lifeless body just outside, they begin to see more clearly where their lives are headed. They are aware of the danger, but it is shocking to see this up close and look at the dead body of a pregnant woman. Pregnancy would end them all, according to Valerie, because the baby in their bellies blinds runaway women with blue tickets: "Your baby is diverting your blood supply, Valerie said. Your body is in danger but the baby will have you ignore this. The baby wants to survive at all costs, the baby doesn't care about you. It's disgusting. You think you have agency, but it's all just biology" (2020, p. 211). Valerie has different opinions about having a baby, and for her, getting pregnant is the biggest mistake. Having a baby means living the lives of others. For not seeing this, she is angry at them. Maybe it is tempting to get pregnant because it is forbidden, or having a baby is an adverse psychological reaction against the system's impositions:

I don't know why you want to do this. I don't know why you gave it all up, Valerie continued. All I ever wanted was freedom, all I wanted was to know that my life wasn't moving towards this dead end, but I knew it was, ever since I was twelve years old. I knew the shape of my life before I even understood what it meant. (2020, p. 212)

Freedom does not mean trying to do what you might not be able to do. In reality, it is the freedom to decide with awareness and reason, free from prohibitions and impositions. Creating a world where women can choose freely and are not subject to prejudice or gender discrimination is one of the most important tasks in this context. The full enjoyment of freedom is linked to the right to choose. Whether male or female, if they have the right to make this choice, they have a chance to experience freedom, at least within a certain framework.

For Valerie, it is nonsensical to start a family, have a baby, live with a suitable partner, and fill your life with these. A woman could not be free by having a baby, establishing a family, obeying her husband. It is a hoax of the system and others are too blind to see it: 
You think the secret to happiness or whatever lies in our so-called fulfilment. You think that family fixes everything, and I will tell you now that it does not, and I'm sorry to break it to you, I'm sorry that your body has pulled such a stunt, such a dirty fucking trick, and that you can never go back. You will regret it every day of your life. (2020, p. 212)

The so-called choices and the presumed free-will decisions drive Marisol, Calla, and other pregnant women to regret and disappointment. Valerie tries to deliver a message which perhaps implies that no one is likely to escape in the system, but there is no use understanding that anymore.

\section{The Dark Feeling Brought into the World at the Beach}

Calla knows that they are getting closer to the border when they get to the beach. There is little time left for her baby to be born. Despite this, she realizes that she has not felt the excitement she has in her all along. The thought that people in childbirth, unlike animals, have to look after their babies for a long time sounds harsh when she first hears about it. While she is thinking about all this in the tent they set up, Calla wants to take a walk when Marisol is asleep, and never come back, leaving everyone behind. As she walks, she feels the water coming, and makes her way to the first beach house she sees. Just before giving birth, she feels alone and scared. When she reaches the house she realizes that it belongs to a woman with a white ticket and imagines herself in her place. Outside the house, Calla with the blue ticket and the woman with the white ticket inside are part of the lottery. Although Calla objects to this system, she feels that she wants a white ticket: "White-ticket. Looking in the windows was irresistible, looking in at the life I had been found unworthy of. Loving, and being loved. It made my heart beat quickly and bile rise in my throat" (2020, p. 226). Calla not only envies the woman's life but also dreams of starting a beautiful family with R. Her mind is still in the relationship with the baby's father. A domestic role is manifested in Calla's subconscious, and the thoughts of motherhood, having a beautiful family, raising children makes her, not a person who opposes the whole system, but someone who rebels against only one rule of her determined life.

After entering the house quietly, Calla approaches the mother from behind who has her baby sleeping in her arms and closes her mouth so that she would not yell. She has no bad intentions; she just wonders what to do during birth. Now that she is alone, 
she has to give birth to her baby on her own, and she has no idea about it, so she feels too scared: "Well, and then you push the baby out. She motioned vaguely. The baby will come out on a cord, and you have to cut the cord, but not too soon. You have to wait until the placenta comes out, that's the red thing on the end, there's no mistaking it when it comes" $(2020$, p. 228). As the woman explains, Calla understands how difficult a process is ahead of her. She does not know if it is worth taking all this pain to be a mother, to get to know the female body in every way, not to accept the life set for her, and break the rules. As the woman continues to give details, Calla realizes what motherhood means:"You'll watch the baby every second of the day. You'll be convinced they're dying. You'll hold them to your body and weep. Sometimes you will think of killing them yourself" $(2020$, p. 229). When the woman sees that Calla does not have a white ticket, she feels how much trouble Calla is in. However, according to the woman, the real trouble is not the emissaries, but motherhood itself.

Since motherhood is the biggest trouble haunting a woman, it has become a phenomenon that restricts freedom, affects women's choices, takes almost all of their time, and leaves them dependent on a living being:"I don't mean the emissaries, though they will surely find you, she said. I mean the other trouble, the motherhood trouble. The trouble that doesn't leave you" $(2020$, p. 229). It seems that this trouble would never let Calla go. Seeing how the baby is put to sleep, Calla notices that the baby's father is sleeping pleasantly and peacefully in the room with the door open and realizes that the mother has to undertake everything in the domestic role. Man is just a living creature that works, has intercourse with women, impregnates them, and pursues his pleasures. Woman is in the opposite position: "I have not slept a full night in months, the woman told me, in the hall. I long to sleep the sleep of the fathers" (2020, p. 231). Despite asking for help, Calla feels how lonely she is when she receives the refusal. After leaving Marisol, she has to deal with everything herself, and there is little time left until the baby is born: "I was alone again and it felt right. The word abandoning came into my head" (2020, p. 232).

Calla feels all the pain and fear while she is giving birth to the baby. She just knows she is ready to do anything for the baby, not knowing how she feels about the creature coming out between her legs. When the baby is born, no word other than surrender comes to her mind. She is not ready to value judgment about the baby; she just wants to embrace it. For now, her desire is only about having the baby and she is ready to sacrifice anything for it: 
Surrender. The baby was still screaming but her skin changed from purple to red. Alien sea-creature. Surrender. I didn't know if I loved her from the first second, I was too afraid to make those sorts of value judgements, but I knew that I would die for her, and that was more important. Surrender. I held my daughter. I pressed her skin against mine. (2020, p. 235)

Baby Nova would be the second thing that determines Calla's life after the lottery. She has to make every decision and choice accordingly. Calla feels how attached she is to the baby as she spends time with her. She realizes how difficult her life has become. While she is taking care of the baby in the tent, she hears voices; someone is coming. As she has just given birth and is getting used to her baby, everything ends for Calla. She is caught with her baby. It's over. When she realizes that Doctor $A$ is standing there in the distance, out of surprise, Calla does not know what to do. She is hunted by the system she defies, and despite all the dangers she faces and all the rules she opposes, she is finally caught.

\section{The Border Between Motherhood and Letting Go}

While there are no clear and enlightening explanations about the world within the border and beyond, it is obvious that this marks the space in which women should live the life determined by the lottery. This border also points to the invisible pressure on female identity and psychological hegemony. Calla has reached the border but only in the hands of the emissaries. Her baby Nova is now in the hands of others. Calla, who checks around with eyes full of anger and hate, has no choice, "Honestly, Calla. You don't have a choice" (2020, p. 242), just as the lottery is drawn at the beginning of the novel, others are still deciding on Calla's life. When the blue ticket comes out of the lottery, Calla, who does not accept the life set for her and does not follow the rules, eventually falls into the same situation and becomes an example of the vicious circle of women. No matter what they did, they could only make choices as much as they were allowed to. They would do whatever the women were told. Calla knows she wants the white ticket and longs to be with her baby. Her goal is not to oppose the impositions of the system but to have the white ticket, the other possibility of the lottery. As long as she reunites with her baby.

It is too late now and there is no chance of seeing Nova again. She has lost her baby. Her baby, whom she risked everything and opposed the system to give birth, is now 
given to another family. She loses the creature that defines her female identity despite all her struggle. After all, to what extent can a woman whose life has already been determined do what she wants? Although Calla thinks she is making a choice, she finally realizes that it is not a choice of her own free will. She has nothing in her own hands. As a result of her choice, the baby she gave birth to has been taken from her hand in a snap:

I'm going to tell you the truth, because I respect you, he said. You weren't given a blue ticket because of anything you did or anything you are. It was random. It could have happened to any of you. There's no deserving. There is no order-at least not one that governs the lottery. There's a yes and a no, and that's all. And yet see how it became true, see how you fulfilled your destiny, how you even relished the blue, at first? Don't interrupt me. I know that you were happy for quite some time. But you couldn't accept it; you thought you were better than what you were given. (2020, p. 248)

Doctor A analyses Calla well and says that she is an insatiable person. Calla thinks she would be happy when she decides on her own will, but that seems impossible. Despite all this, Calla would be given a new chance, one last to make her life settled. Seeing himself as an individual seeking freedom leads Calla to rebellion and resistance. Anyone who is part of the system or even a pawn is uncomfortable with this situation. Doctor A also says in this context that Calla is a character who is not satisfied with what she has. In doing so, the doctor tries to reduce Calla to a traditional gender role and implies that she should accept the role assigned to the women.

What is punishment, according to Doctor A, has been considered the only reality in Calla's life. She can perceive herself and her life as real only with the baby. Other experiences, events, and people seem like an illusion to her. Still, she is pursuing freedom in her way and thinks she chooses a gagging way: "How could he not know that that punishment had been the best and truest part of my life? Possibly I was not the sort of person who should be a mother, but I had heard what was calling through my body and I chose the burden of it. I chose freedom, even if to some it looked like the opposite" (2020, p. 249). Whatever is done, whatever decision is made, there is no such thing as freedom for women. Calla chooses to be a mother of her own will, against the rules of the blue ticket. She alone struggles with dangers, but in the end, her baby is taken 
away and all that she did for motherhood, femininity, female identity, and free will is a waste. Giving her a chance one more time means that her life is determined by the system. Calla's life would be redefined and she would have to obey the rules, otherwise, her life would end irreversibly.

\section{Conclusion}

Calla's long journey which started with a lottery deciding on her life ends with almost every corrosive and aggressive feeling of disappointment, anger, loss, in-betweenness and failure since she was caught at the border, her child was taken away from her and she is with a huge emptiness in hand after all the resistance, revolt, and toilsome perseverance. In the game of chance between a 'carpe diem' mood and a full-blown duty into motherhood is, in fact, a verdict by the unknown and invisible factors surrounding every woman in the dystopian society with peculiarities. For Calla, whose life has been already pre-determined with a blue ticket coming out of a sort of a jukebox as a result of the lottery, it is never easy to accept that something else decides what is 'good' or 'the best' for her. That is why her rebellion begins to earn the right to choose to become a mother although she has no idea of how it would feel to experience that. It seems ridiculously brave for Calla to take every apparatus of this oppressive society just to become something she has no idea about, but it is the rebellion that matters in this long journey of self-awareness, self-realization, and tenacity.

Calla is not a woman who is sure of herself about what she wants from life whether it is becoming a mother or having casual affairs with men. She never brings out the sense that the narrative is full of a strong inclination to have children. Everything is based on the concept of choice or chance. Calla's life seems somehow devoid of meaning and that is most probably why she wants to add meaning to her life by resisting the oppressions and monotony of captivity. In some instances, she becomes desperate and feels that she has to watch the world passing by. The readers get the sense of how she feels surrounded by the vulnerability delivered through the hypnotic prose of Mackintosh in which there seems a necessity for Calla to experience a rise after the fall she is forced to encounter due to the lottery.

What seems so real and yet devastating are Calla's doubts and fears which are oddly familiar. The spirit and audacity of Calla, her slow but striking downward spiral with a brilliantly depicted life trajectory seems to fall apart in the dystopian world where all 
other females go and receive a ticket determinant on the maturity of menstruation to be able to discover what lies in their fate. Even though the implication of having a choice in life is clearly emphasized in the novel, once the tickets are delivered, there is no going back for the women no matter how they yearn for the other life they are not supposed to be involved in.

Women are reduced by patriarchal culture to the state of an "object" used by men. In any field of life, women have not been able to acclaim the role of a "subject." To exemplify that, there is a majority of men who still consider their partners as sex dolls in terms of sexual activity instead of an active shareholder of the pleasure. For Irigaray, the laws of the patriarchal system can be subverted by women through idiosyncrasies. Women may also re-shape their pre-set positions through their progressive attitudes in prose. Through their writings, women have the ability to correct the male-dominant writing's skewed description of them. Writing, thus, has been for centuries the main way of communicating and dictating thoughts to the masses.

Calla tries her utmost to stand against the rules of the system in the dystopian world as if she wants to see Frost's 'the road not taken'. It is for sure that Calla and women like her believe they are given the wrong ticket because it is a matter of choice and the life that has been chosen for them is not at all what they would choose on their own. Considering the fact that free will and social expectations might collide and the system that women are dragged into is flawed, women like Calla are ready to defy the ruling system no matter what the cost is. In a world where social roles are dictated by a ticket, emissaries take everything under control including guarding borders and checking points, there is the pervasive fear of the unknown which Sophie Mackintosh generally delves into to make clear what happens to women when they disobey and she enjoys betrayal.

Although there seems no clear answer for the major issues in the novel about the system, of what is behind the lottery, who constructs this kind of world and rules it, why women are dragged into such positions, it is this sense of fear that helps maintain the status quo. Besides, the sense of fear is supported by the unknown and the ways of punishment are also unclear in the world where women are forced to continue the roles given to them which is a clear sign of conventionality constructed by this oppressive patriarchy. The world Calla and the others are surrounded by is like how Foucault explains this example with Jeremy Bentham's "panopticon" in which "[...] everything 
must be observed, seen, transmitted [...]" $(1995$, p. 22). What we read in the journey of Calla's insurrection is not just about overcoming the system, instead, the narrative reveals a powerful questioning of the philosophical structure of the choice which is not given to the women in this nightmarish society except for what is offered with a blue and white ticket. Mackintosh's attitude towards her narratives is directly related to what Cixous asserts in the famous article "The Laugh of Medusa": "Woman must write her self: must write about women and bring women to writing, from which they have been driven away as violently as from their bodies ... Woman must put herself into the text - as into the world and into history - by her own movement" (p. 875). The fact that women defend their identities by writing and that discrimination is brought to the agenda through female characters created in the narratives shows the purpose of Mackintosh in his novel Blue Ticket. The most striking examples of gender discrimination, both through the eyes of the author and through the main character, Calla, are discussed in the novel.

The definition of women as "two-legged wombs" by Cixous works entirely within the sphere of interest of patriarchal cultures, denying women any freedom of sexual preference or way of life. There is no expectation of a revolution in this woman-led narrative and Calla is not seeking a justification or challenging the system's construct. Calla is Cixous's woman who is "... confined to the narrow room in which they've been given a deadly brainwashing" (2008, p. 877). It is all about what Calla's body demands to have a child and how she cannot ignore that 'dark feeling' anymore which ends up with the resistance and rebellion she feels in her quest which she is dragged into. Stereotypical roles of men and women are strengthened by social and cultural values, which emphasize highly conventional expectations about gender. It cannot be denied that stereotypes about men and women have a dramatic effect on our opinions about how both sexes should or should not behave. We have been taught to behave according to determined patterns since childhood. We are taught about ideal behaviour. Boys are expected to be strong and courageous, while girls are gentle and obedient.

Sophie Mackintosh has created a tense, ambiguous, and mysterious narrative in her novel, Blue Ticket, which, on the one hand, refers to all kinds of discrimination and oppression women face today, on the other hand, she has created a protagonist who defends women's desires and rights to make choices with their own will. Calla's journey, her introspection, and her observations about women as well as the internal conflict she is never able to ignore are scrutinized with this emotionally wrought and moving 
narrative. Positioning today's society, where gender discrimination is experienced at the highest level, to a dystopian regime, the author meticulously examines the concepts of motherhood, femininity, wifehood, and female identity. In doing so, she strikingly shows how high the price women have paid in this system. Every choice and uprising Calla makes is a reference to the issue of women and the irreparable consequences of gender discrimination in today's society.

Peer-review: Externally peer-reviewed.

Conflict of Interest: The author has no conflict of interest to declare.

Grant Support: The author declared that this study has received no financial support.

Hakem Değerlendirmesi: Dış bağımsız.

Çıkar Çatışması: Yazar çıkar çatışması bildirmemiştir.

Finansal Destek: Yazar bu çalışma için finansal destek almadığını beyan etmiştir.

\section{References}

Althusser, L. (2008). Ideology and Ideological State Apparatuses. London, Verso.

Booker, M. K. (1994). The Dystopian Impulse in Modern Literature: Fiction as Social Criticism. Westport, CT: Greenwood.

---. (1994). Dystopian Literature: A Theory and Research Guide. Westport, CT: Greenwood, Print.

Cixous, H. (1996). Sorties. In P. Rice and P. Waugh. (Eds.) Modern Literary Theory: A Reader (pp. 137-144). New York: Arnold.

---. (2008). "The Laugh of the Medusa". Trans. Keith and Paula Cohen. Signs 1.4 (1976): 875-893.

Claeys, G. (2010). "The Origins of Dystopia: Wells, Huxley and Orwell”. G. Claeys (Ed.) The Cambridge Companion to Utopian Literature (pp. 107-31) Cambridge: Cambridge UP.

Fiske, S. T., \& Stevens, L. E. (1993). What's so special about sex? Gender stereotyping and discrimination. In S. Oskamp \& M. Costanzo (Eds.), Claremont Symposium on Applied Social Psychology, Vol. 6. Gender issues in contemporary society (pp. 173-196). Sage Publications, Inc.

Foucault, M. (1995) ."Discipline \& Punish". The Birth of Prison. Translated by Alan Sheridan. New York, Vintage Books.

Irigaray, L. (1985). "This Sex Which Is Not One” This Sex Which Is Not One. Ithaca, NY: Cornell UP, 23-33.

---. (2004). "The Power of Discourse and the Subordination of the Feminine." Literary Theory: An Anthology. Rivkin, Julie, and Michael Ryan (Eds.) Malden, MA: Blackwell Pub., 570-574.

---. (2004). "Commodities amongst Themselves." Literary Theory: An Anthology. Rivkin Julie, and Michael Ryan (eds.) Malden, MA: Blackwell Pub., 574-578. 
Kolmar, Wendy K., and Frances B. (2005). "'Feminism" from The Feminist Dictionary." Feminist Theory: A Reader. Boston: McGraw-Hill Higher Education, 7-11.

Kumar, K. (1987). "Anti-Utopia, Shadow of Utopia." Utopia and Anti-utopia in Modern Times. Oxford, UK: Blackwell, 99-130.

Mackintosh, S. (2020). Blue Ticket. New York, USA, Doubleday.

Morris, P. (1993). Literature and Feminism: An Introduction. Oxford, UK: Blackwell.

Ruppert, P. (1986). Reader in a Strange Land: The Activity of Reading Literary Utopias. Athens: U of Georgia. 